\title{
THE PHYSIOLOGIC SIGNIFICANCE OF THE SECRETION OF ENDOGENOUS INSULIN INTO THE PORTAL CIRCULATION. I. COMPARISON OF THE EFFECTS OF GLUCAGON-FREE INSULIN ADMINISTERED VIA THE PORTAL VEIN AND VIA A PERIPHERAL VEIN ON THE MAGNITUDE OF HYPOGLYCEMIA AND PE- RIPHERAL GLUCOSE UTILIZATION ${ }^{1}$
}

\author{
By LEONARD L. MADISON AND ROGER H. UNGER \\ (From the Department of Medicine, University of Texas Southwestern Medical School, Dallas, \\ Texas, and the Department of Medicine, Veterans Administration Hospital, \\ Dallas, Texas)
}

(Submitted for publication October 29, 1957; accepted January 16, 1958)

The metabolic consequences of exogenous insulin which is administered parenterally may differ from those of the endogenously secreted hormone for at least two reasons: exogenous insulin may be altered in its commercial preparation; its activity may be different because it enters the body through the systemic circulation. Under physiologic conditions, insulin is secreted by the pancreatic betacytotropic cells into the branches of the portal circulation, traversing the liver prior to entry into the systemic circulation where it is bound in a variety of tissues; this binding is apparently intimately associated with insulin activity $(1-4)$. Theoretically, insulin secreted into the portal vein, because it passes directly into the liver, may have a metabolic effect different from insulin administered peripherally: all of the insulin reaches the liver, and may therefore increase the hepatic effect and decrease the peripheral effect (qualitative difference); part of the insulin may be destroyed by hepatic insulinase reducing the net amount available (quantitative difference); finally, there may be no significant physiologic alteration by this initial passage through the liver.

The purpose of this study was to determine whether the initial passage of insulin through the liver altered its subsequent metabolic activity qualitatively or quantitatively by comparing the effect of glucagon-free insulin ${ }^{2}$ administered via the portal and via a peripheral vein on the magnitude of the hypoglycemia and the magnitude of the change in peripheral glucose utilization. The

1 This work was supported in part by a grant from The Upjohn Company.

2 The supply of glucagon-free insulin was furnished by $\mathrm{Dr}$. W. R. Kirtley of the Eli Lilly Company, Indianapolis, Indiana. arteriovenous (A-V) glucose difference and the arteriovenous glucose difference/arterial glucose concentration $(\mathrm{A}-\mathrm{V}) / \mathrm{A}$ were used as the parameters for measuring changes in peripheral glucose utilization $(5,6)$.

\section{METHODS}

Sixteen experiments were performed on eight healthy adult dogs, housed in individual runs and maintained on a diet of constant composition for at least two weeks prior to each experiment. All procedures were performed in an airconditioned constant temperature room on dogs in the postabsorptive state. Sodium pentobarbital (Nembutal®, $25 \mathrm{mg}$. per $\mathrm{Kg}$.) was used for anesthesia. Two experiments were conducted in random order on each dog: during one, glucagon-free insulin ( $0.07 \mathrm{U}$ per $\mathrm{Kg}$.) was administered over a two minute period into a large tributary of the portal vein, and during the other, the same amount was given into a peripheral vein in the foreleg. In those instances when insulin was given via a peripheral vein, a sham operation was performed and saline injected into a tributary of the portal vein while the dog was simultaneously receiving insulin in a foreleg vein. This additional control, sham operation was necessary since other data from our laboratory indicated that one of the acute effects of operation was an augmentation of peripheral glucose utilization.

Arterial and venous blood samples were drawn simultaneously from the femoral artery on one side, and from the contralateral femoral vein by means of indwelling Cournand needles. About 30 minutes after the operation was completed, two control blood samples were obtained at 10 minute intervals prior to insulin injection, and thereafter usually at 5 minute intervals for the first 30 minutes, at 10 minute intervals for the following 30 minutes and at 15 minute intervals for the ensuing 30 to 60 minutes.

To prevent glycolysis, blood samples were collected in chilled tubes containing sodium fluoride. Blood glucose was determined in duplicate by the Somogyi copper iodometric method on $5 \mathrm{ml}$. of blood filtrate prepared immediately from $2 \mathrm{ml}$. blood samples, thereby providing a 
TABLE I

Changes in femoral arterial and venous glucose concentrations after glucagon-free insulin (0.07 $U$ per $K g$. administered into a foreleg vein

\begin{tabular}{|c|c|c|c|c|c|c|c|c|c|c|c|c|c|c|c|c|c|c|}
\hline \multirow[b]{2}{*}{ Dog } & & \multicolumn{2}{|c|}{ Control } & \multicolumn{15}{|c|}{ Time after insulin administration } \\
\hline & & $0-10$ & $\mathbf{0}$ & 5 & 10 & 15 & 20 & 25 & 30 & 40 & 50 & 60 & 70 & 80 & 90 & 105 & 120 & 135 \\
\hline \multirow[t]{4}{*}{$1 *$} & Ał & 93.7 & 96.0 & 90.8 & 82.4 & 66.0 & 56.0 & & 59.0 & 71.3 & 79.0 & 82.0 & 86.8 & 91.0 & 87.6 & 89.9 & 88.8 & 93.9 \\
\hline & V\$ & 92.3 & 96.2 & 86.2 & 78.6 & 60.0 & 48.0 & & 47.8 & 59.0 & 61.0 & 69.0 & 68.1 & 75.0 & 71.4 & 75.0 & 81.4 & 84.0 \\
\hline & A-V\| & 1.4 & -0.2 & 4.6 & 3.8 & 6.0 & 8.0 & & 11.2 & 12.3 & 18.0 & 13.0 & 18.7 & 16.0 & 16.2 & 14.9 & 7.4 & 9.9 \\
\hline & A-V/A & 0.014 & -0.002 & 0.050 & 0.046 & 0.090 & 0.142 & & 0.189 & 0.172 & 0.227 & 0.151 & 0.215 & 0.175 & 0.184 & 0.165 & 0.083 & 0.105 \\
\hline \multirow[t]{4}{*}{$6 *$} & $\mathbf{A}$ & 74.0 & 74.6 & 76.0 & 61.0 & 50.4 & 47.4 & & 39.9 & 53.0 & 61.4 & 61.4 & 65.6 & 68.3 & 65.6 & 66.7 & 70.0 & 78.9 \\
\hline & V & 72.4 & 72.8 & 70.8 & 56.4 & 46.8 & 40.7 & & 35.0 & 43.3 & 53.2 & 53.2 & 55.6 & 58.2 & 54.8 & 61.7 & 67.0 & 76.7 \\
\hline & $A-V$ & 1.6 & 1.8 & 5.2 & 4.6 & 3.6 & 6.7 & & 4.9 & 9.1 & 8.2 & 10.8 & 10.0 & 10.1 & 10.8 & 5.0 & $\mathbf{3 . 0}$ & 2.2 \\
\hline & A-V/A & 0.021 & 0.024 & 0.068 & 0.075 & 0.071 & 0.141 & & 0.122 & 0.171 & 0.133 & 0.168 & 0.152 & 0.147 & 0.164 & 0.074 & 0.042 & 0.027 \\
\hline \multirow[t]{4}{*}{$5^{*}$} & A & 82.0 & 78.0 & 78.2 & & 70.1 & 67.2 & & 72.8 & 78.0 & 81.0 & 82.0 & 85.0 & 83.6 & 85.6 & 82.7 & 87.2 & 87.8 \\
\hline & $\mathbf{V}$ & 79.0 & 75.5 & 74.5 & & 62.3 & 55.4 & & 57.3 & 64.2 & 66.0 & 69.6 & 73.2 & 75.7 & 76.1 & 75.0 & 78.0 & 79.8 \\
\hline & $A-V$ & 3.0 & 2.5 & 3.7 & & 7.8 & 11.8 & & 15.5 & 13.8 & 15.0 & 12.4 & 11.8 & 7.9 & 9.5 & 7.7 & 9.2 & 8.0 \\
\hline & A-V/A & 0.036 & 0.033 & 0.047 & & 0.111 & 0.175 & & 0.212 & 0.176 & 0.185 & 0.151 & 0.138 & 0.094 & 0.110 & 0.093 & 0.105 & 0.091 \\
\hline \multirow[t]{4}{*}{$8^{*}$} & $\mathbf{A}$ & 85.6 & 88.1 & 85.9 & 74.0 & 61.6 & 56.8 & & 62.2 & 75.0 & 79.8 & 82.7 & 83.2 & 88.9 & 88.1 & 89.2 & & \\
\hline & V & 85.0 & 88.1 & 85.6 & 69.0 & 60.2 & 53.0 & & 52.2 & 67.0 & 72.2 & 70.3 & 75.4 & 81.0 & 82.7 & 84.5 & & \\
\hline & A-V & 0.6 & 0.0 & 0.3 & 5.0 & 1.4 & 3.8 & & 10.0 & 8.0 & 7.6 & 12.4 & 7.8 & 7.9 & 5.4 & 4.7 & & \\
\hline & A-V/A & 0.007 & 0.000 & 0.003 & 0.067 & 0.022 & 0.066 & & 0.160 & 0.106 & 0.095 & 0.149 & 0.094 & 0.089 & 0.061 & 0.052 & & \\
\hline \multirow[t]{4}{*}{$3^{*}$} & $\mathbf{A}$ & 79.8 & 80.0 & 77.3 & 67.2 & 58.0 & 54.4 & & 68.2 & 76.0 & 77.3 & 80.2 & 82.7 & 81.4 & 75.6 & 79.2 & 79.8 & \\
\hline & $\mathrm{V}$ & 79.0 & 80.2 & 77.0 & 61.0 & 52.9 & 46.5 & & 58.6 & 68.2 & 71.4 & 73.3 & 78.2 & 75.0 & 72.6 & 74.0 & 78.0 & \\
\hline & A-V & 0.8 & 0.0 & 0.3 & 6.2 & 5.1 & 7.9 & & 9.6 & 7.8 & 5.9 & 6.9 & 4.5 & 6.4 & 3.0 & 5.2 & 1.8 & \\
\hline & A-V/A & 0.010 & 0.000 & 0.003 & 0.092 & 0.087 & 0.140 & & 0.140 & 0.102 & 0.076 & 0.086 & 0.054 & 0.078 & 0.039 & 0.065 & 0.022 & \\
\hline \multirow[t]{4}{*}{$4^{*}$} & A & & 88.3 & & & 56.2 & 51.4 & 56.5 & 72.2 & 76.0 & 82.8 & 81.5 & & 87.8 & 87.2 & 98.0 & & \\
\hline & V & & 86.7 & & & 53.3 & 48.8 & 50.0 & 61.8 & 70.4 & 77.0 & 77.0 & & 84.6 & 82.0 & 82.6 & & \\
\hline & $A-V$ & & 1.6 & & & 2.9 & 2.6 & 6.5 & 10.4 & 5.6 & 5.8 & 4.5 & & 3.2 & 5.2 & 5.4 & & \\
\hline & A-V/A & & 0.018 & & & 0.051 & 0.050 & 0.115 & 0.144 & 0.074 & 0.070 & 0.055 & & 0.036 & 0.059 & 0.061 & & \\
\hline \multirow[t]{5}{*}{$2 *$} & $\mathbf{A}$ & 88.4 & 90.7 & 89.7 & 82.4 & 73.0 & 63.6 & 55.4 & 49.7 & 47.2 & 50.8 & 57.8 & 67.0 & 73.4 & 76.2 & & & \\
\hline & V & 86.7 & 90.6 & 88.8 & 81.2 & 72.0 & 63.0 & 55.3 & 49.4 & 45.4 & 48.2 & 55.0 & 63.2 & 69.0 & 71.6 & & & \\
\hline & A-V & 1.7 & 0.1 & 0.9 & 1.2 & 1.0 & 0.6 & 0.1 & 0.3 & 1.8 & 2.6 & 2.8 & 3.8 & 4.4 & 4.6 & & & \\
\hline & $\mathrm{A}-\mathrm{V} / \mathrm{A}$ & 0.019 & 0.001 & 0.010 & 0.014 & 0.013 & 0.009 & 0.002 & 0.006 & 0.036 & 0.052 & 0.048 & 0.057 & 0.059 & 0.060 & & & \\
\hline & Time & $0-10$ & $0 \downarrow$ ** & 10 & 20 & 30 & 40 & 50 & $60 \uparrow t \dagger$ & $\dagger 70$ & 80 & 90 & 100 & 110 & 120 & 135 & 150 & 165 \\
\hline \multirow[t]{4}{*}{$10 \dagger$} & $\mathbf{A}$ & 75.0 & 76.6 & 69.5 & 59.2 & 53.2 & 48.0 & 46.1 & 45.6 & 54.0 & 67.8 & 67.2 & 71.6 & 80.8 & 79.7 & 82.4 & 85.8 & 83.8 \\
\hline & V & 69.5 & 72.7 & 67.9 & 59.0 & 53.2 & 47.3 & 44.0 & 43.8 & 44.3 & 56.1 & 58.4 & 64.2 & 72.0 & 72.0 & 74.9 & 77.8 & 72.0 \\
\hline & A-V & 5.5 & 3.9 & 1.6 & 0.2 & 0.0 & 0.7 & 2.1 & 1.8 & 9.7 & 11.7 & 8.8 & 7.4 & 8.8 & 7.7 & 7.5 & 8.0 & 11.8 \\
\hline & $A-V / A$ & 0.073 & 0.050 & 0.023 & 0.003 & 0.000 & 0.014 & 0.045 & 0.038 & 0.179 & 0.172 & 0.130 & 0.103 & 0.108 & 0.096 & 0.091 & 0.093 & 0.140 \\
\hline
\end{tabular}

* Insulin infused into a foreleg vein over a two minute period.

$\dagger$ Insulin infused into a foreleg vein over a 60 minute period.

$\ddagger$ Arterial glucose concentration.

$\$$ Venous glucose concentration.

means for the valid measurement of $\mathrm{A}-\mathrm{V}$ glucose differences as little as $2 \mathrm{mg}$. per cent $(5,7,8)$.

\section{RESULTS}

The changes in femoral arterial and venous glucose concentrations, $\mathrm{A}-\mathrm{V}$ glucose difference, and $(\mathrm{A}-\mathrm{V}) / \mathrm{A}$, following the peripheral and portal administration of glucagon-free insulin are listed in Tables I and II. Typical data from two paired experiments, comparing the effects of the two routes of administration, are shown in Figures 1 and 2 .

In each dog, the peripheral injection of insulin increased peripheral glucose utilization to a significantly greater extent than did the portal ad-
II Arteriovenous glucose difference.

I Arteriovenous glucose difference/arterial glucose concentration.

$* * \downarrow$ Start infusion.
t† $\uparrow$ End infusion.

ministration. The mean increases of $6.9 \mathrm{mg}$. per cent in $\mathrm{A}-\mathrm{V}$ glucose difference and 0.097 in $(A-V) / A$ after the injection of insulin into a foreleg vein were significantly greater $(\mathrm{p}=$ $<0.01$ ) than the mean increases of $4.6 \mathrm{mg}$. per cent in $\mathrm{A}-\mathrm{V}$ glucose difference and 0.064 in $(A-V) / A$ after the intraportal injection of the same dose of insulin (Table III, Figures 3 and 4). Similarly, the mean peripheral utilization index of 80 , computed according to the method of Somogyi (9), after insulin delivered into a peripheral vein was significantly greater $(p=<0.01)$ than the mean index of 56 , following the intraportal route of administration (Table IV). 
TABLE II

Changes in femoral arterial and venous glucose concentrations after glucagon-free insulin (0.07 U per $K g$.) injected into a branch of the portal vein

\begin{tabular}{|c|c|c|c|c|c|c|c|c|c|c|c|c|c|c|c|c|c|}
\hline \multirow[b]{2}{*}{ Dog } & & \multicolumn{2}{|c|}{ Control } & \multicolumn{14}{|c|}{ Time after insulin administration } \\
\hline & & $0-10$ & $\mathbf{0}$ & 5 & 10 & 15 & 20 & 25 & 30 & 40 & 50 & 60 & 75 & 80 & 90 & 105 & 120 \\
\hline \multirow[t]{4}{*}{$1^{*}$} & A & 87.5 & 89.7 & & 79.0 & & 60.0 & & 67.0 & 72.3 & 74.0 & 69.0 & 74.0 & & 83.0 & 84.4 & 81.5 \\
\hline & V8 & 85.0 & 86.8 & & 77.4 & & 51.0 & & 58.8 & 62.2 & 59.8 & 59.3 & 67.2 & & 76.0 & 75.1 & 74.0 \\
\hline & $A-V \|$ & 2.5 & 2.9 & & 1.6 & & 9.0 & & 8.2 & 10.1 & 14.2 & 9.7 & 6.8 & & 7.0 & 9.3 & 7.5 \\
\hline & A-V/Aף & 0.028 & 0.037 & & 0.020 & & 0.150 & & 0.123 & 0.139 & 0.191 & 0.140 & 0.091 & & 0.084 & 0.108 & 0.092 \\
\hline \multirow[t]{4}{*}{$6^{*}$} & $\mathbf{A}$ & 82.7 & 87.0 & 81.4 & 68.0 & 56.4 & 52.8 & 54.8 & 59.2 & 60.2 & 66.0 & 69.7 & 68.2 & & 73.7 & 78.0 & 75.0 \\
\hline & $\mathrm{V}$ & 82.7 & 85.0 & 77.2 & 63.0 & 51.0 & 46.6 & 47.8 & 52.0 & 53.6 & 56.0 & 58.0 & 60.8 & & 67.4 & 75.8 & 75.0 \\
\hline & A-V & 0.0 & 2.0 & 4.2 & 5.0 & 5.4 & 6.2 & 7.0 & 7.2 & 6.6 & 10.0 & 11.7 & 7.4 & & 6.3 & 2.2 & 0.0 \\
\hline & $\mathrm{A}-\mathrm{V} / \mathrm{A}$ & 0.000 & 0.022 & 0.051 & 0.073 & 0.096 & 0.117 & 0.124 & 0.121 & 0.110 & 0.151 & 0.167 & 0.108 & & 0.085 & 0.028 & 0.000 \\
\hline \multirow[t]{4}{*}{ 5* } & $\mathbf{A}$ & 78.5 & 85.6 & 81.7 & 67.4 & 67.5 & 70.0 & 76.0 & 78.0 & 84.8 & 78.8 & 76.1 & 81.0 & & 79.1 & 86.7 & 77.7 \\
\hline & V & 77.0 & 84.8 & 81.4 & 65.7 & 64.2 & 63.8 & 66.0 & 69.7 & 78.5 & 69.3 & 68.6 & 73.8 & & 75.0 & 78.9 & 77.0 \\
\hline & A-V & 1.5 & 0.8 & 0.3 & 1.7 & 3.3 & 6.2 & 10.0 & 8.3 & 6.3 & 9.5 & 7.5 & 7.2 & & 4.1 & 7.8 & 0.7 \\
\hline & A-V/A & 0.019 & 0.009 & 0.003 & 0.025 & 0.048 & 0.088 & 0.131 & 0.106 & 0.074 & 0.120 & 0.098 & 0.088 & & 0.051 & 0.089 & 0.009 \\
\hline \multirow[t]{4}{*}{$8^{*}$} & $\mathbf{A}$ & 85.2 & 84.2 & 81.8 & 72.8 & 69.2 & 63.2 & 58.8 & 67.4 & 84.7 & 85.7 & 84.2 & 83.6 & & 83.6 & 83.6 & \\
\hline & $\mathrm{V}$ & 84.2 & 84.2 & 81.8 & 71.4 & 68.0 & 61.7 & 56.4 & 63.8 & 76.3 & 77.8 & 74.4 & 77.0 & & 77.8 & 81.0 & \\
\hline & $A-V$ & 1.0 & 0.0 & 0.0 & 1.4 & 1.2 & 1.5 & 2.4 & 3.6 & 8.4 & $7.9^{\circ}$ & 9.8 & 6.6 & & 5.8 & 2.6 & \\
\hline & $A-V / A$ & 0.011 & 0.000 & 0.000 & 0.019 & 0.017 & 0.024 & 0.040 & 0.053 & 0.099 & 0.092 & 0.116 & 0.079 & & 0.069 & 0.031 & \\
\hline \multirow[t]{4}{*}{$3^{*}$} & A & 90.6 & 89.4 & 84.6 & 75.6 & 71.2 & 67.2 & 66.7 & 67.6 & 71.0 & 78.1 & 83.4 & 84.6 & 85.1 & & & \\
\hline & $\mathrm{V}$ & 89.4 & 88.3 & 84.0 & 73.0 & 68.8 & 64.6 & 63.4 & 63.0 & 66.7 & 73.8 & 76.0 & 79.1 & 80.2 & & & \\
\hline & $\mathrm{A}-\mathrm{V}$ & 1.2 & 1.1 & 0.6 & 2.6 & 2.4 & 2.6 & 3.3 & 4.6 & 4.3 & 4.3 & 7.4 & 5.6 & 4.9 & & & \\
\hline & $\mathrm{A}-\mathrm{V} / \mathrm{A}$ & 0.013 & 0.012 & 0.007 & 0.034 & 0.034 & 0.039 & 0.049 & 0.068 & 0.060 & 0.055 & 0.088 & 0.065 & 0.057 & & & \\
\hline \multirow[t]{4}{*}{$4^{*}$} & A & 93.6 & 95.0 & 81.8 & 69.0 & 58.0 & 64.3 & 70.3 & 73.8 & 76.8 & 80.8 & 85.8 & 88.4 & 89.4 & & & \\
\hline & $\mathrm{V}$ & 93.2 & 92.7 & 82.0 & 66.0 & 56.0 & 60.2 & 65.3 & 68.1 & 73.1 & 73.8 & 84.0 & 86.6 & 87.6 & & & \\
\hline & $\mathrm{A}-\mathrm{V}$ & 0.4 & 2.3 & -0.2 & 3.0 & 2.0 & 4.1 & 5.0 & 5.7 & 3.7 & 7.0 & 1.8 & 1.8 & 1.8 & & & \\
\hline & A-V/A & 0.004 & 0.024 & -0.002 & 0.043 & 0.034 & 0.064 & 0.071 & 0.077 & 0.048 & 0.086 & 0.020 & 0.020 & 0.020 & & & \\
\hline \multirow[t]{5}{*}{$2 *$} & $\mathbf{A}$ & 100.4 & & 105.3 & 91.3 & 86.0 & 78.5 & 75.0 & 72.4 & 80.6 & 86.0 & 91.7 & 96.6 & 98.4 & & & \\
\hline & V & 99.8 & & 102.1 & 90.8 & 85.6 & 78.2 & 74.6 & 70.3 & 78.9 & 84.6 & 90.4 & 96.2 & 98.6 & & & \\
\hline & A-V & 0.6 & & 3.2 & 0.5 & 0.4 & 0.3 & 0.4 & 2.1 & 1.7 & 1.4 & 1.3 & 0.4 & -0.2 & & & \\
\hline & $\mathrm{A}-\mathrm{V} / \mathrm{A}$ & 0.006 & & 0.030 & 0.005 & 0.004 & 0.004 & 0.005 & 0.029 & 0.021 & 0.016 & 0.014 & 0.004 & -0.002 & & & \\
\hline & Time & $0-10$ & $0 \downarrow^{* *}$ & 10 & 20 & 30 & 40 & 50 & $60 \uparrow \dagger \uparrow$ & $\dagger 70$ & 80 & 90 & 105 & 120 & 135 & 150 & 165 \\
\hline \multirow[t]{4}{*}{$10 \dagger$} & A & 83.0 & 83.6 & 73.0 & 66.5 & 64.9 & 66.0 & 66.5 & 68.4 & 76.2 & 84.6 & 83.0 & 81.4 & 83.8 & 83.0 & 83.1 & 81.8 \\
\hline & V & 80.4 & 81.0 & 73.0 & 64.2 & 64.2 & 64.2 & 63.4 & 64.9 & 68.7 & 73.8 & 79.0 & 74.0 & 77.8 & 77.9 & 77.0 & 79.0 \\
\hline & $A-V$ & 2.6 & 2.6 & 0.0 & 2.3 & 0.7 & 1.8 & 3.1 & 3.5 & 7.5 & 10.8 & 4.0 & 7.4 & 6.0 & 5.1 & 6.1 & 2.8 \\
\hline & $\mathrm{A} \cdot \mathrm{V} / \mathrm{A}$ & 0.031 & 0.031 & 0.000 & 0.034 & 0.001 & 0.027 & 0.047 & 0.051 & 0.098 & 0.127 & 0.048 & 0.090 & 0.071 & 0.061 & 0.073 & 0.034 \\
\hline
\end{tabular}

* Insulin infused into a branch of the portal vein over a two minute period.

$\dagger$ Insulin infused into a branch of the portal vein over a 60 minute period.

¥ Arterial glucose concentration.

$\$$ Venous glucose concentration.

II Arteriovenous glucose difference.

I Arteriovenous glucose difference/arterial glucose concentration.

** $\downarrow=$ Start infusion.

†† $\uparrow=$ End infusion.

In contrast to the difference in peripheral glucose utilization, following the intraportal and peripheral injection of insulin, is the similarity in the magnitude of the hypoglycemia which results after both routes of insulin administration. The arterial glucose response after each route of administration, along with the standard deviation of the mean difference between these changes, are shown in Figure 5. There is no significant difference in the magnitude of the hypoglycemia between both routes of administration when calculated either in milligrams or percentage decrease from fasting levels (Table V).
In order to determine whether the changes in peripheral glucose utilization resulting from the intraportal administration of insulin were dependent upon the amount of insulin perfusing the liver per unit of time, an experiment was performed (Dog 10, Tables I and II) in which insulin (0.0017 $\mathrm{U}$ per $\mathrm{Kg}$. per minute) was administered intraportally and intravenously over a one hour period at $1 / 20$ the rate of the previous experiments. If the alterations in the insulin during passage through the liver were rate-limited, a larger difference between the changes after the peripheral and portal infusion of insulin would 


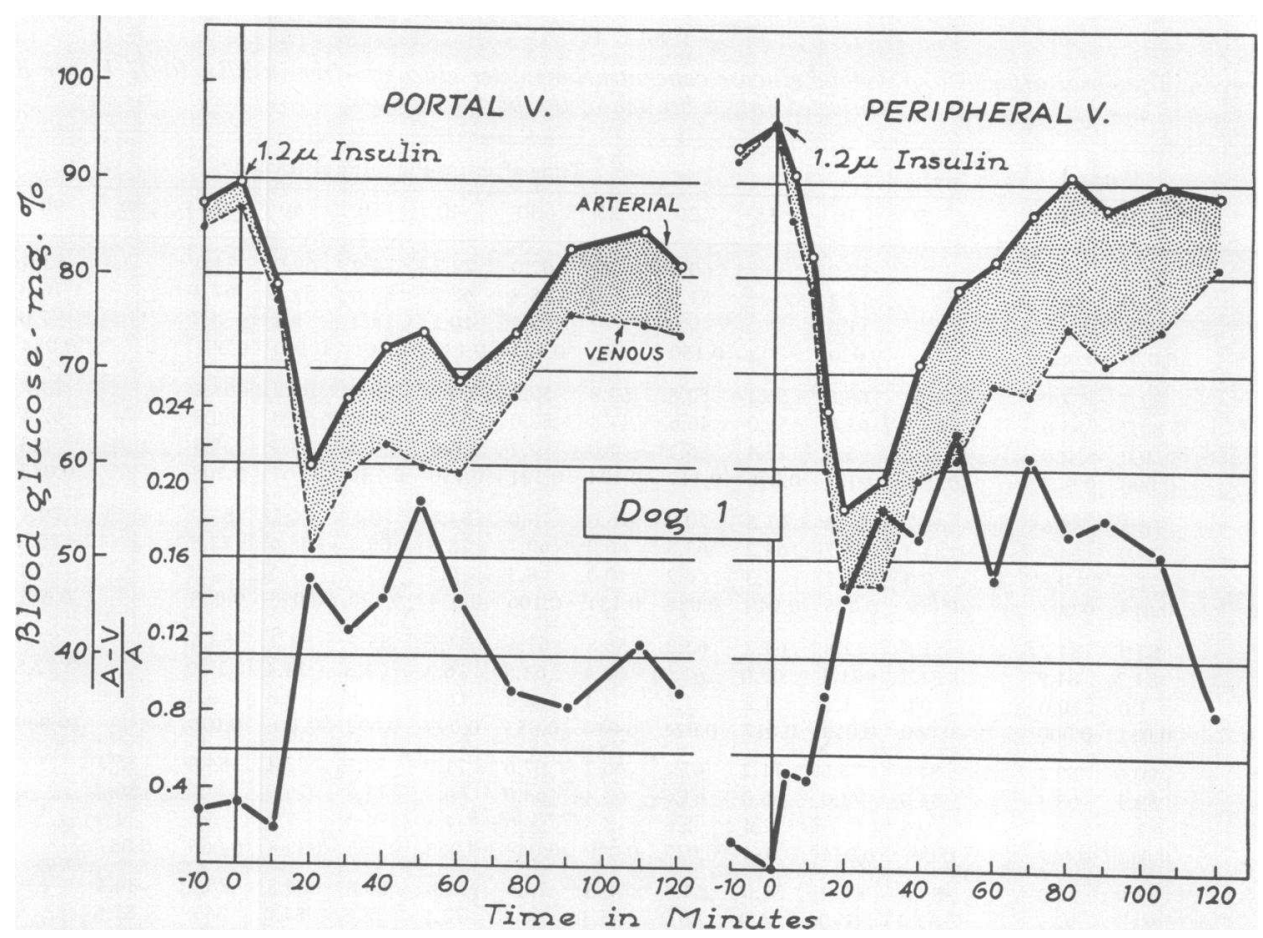

Fig. 1. Administration of Glucagon-Free Insulin (Dog 1)

be forthcoming. Such was not the case; the differences in $(\mathrm{A}-\mathrm{V}) / \mathrm{A}$ and $\mathrm{A}-\mathrm{V}$ glucose difference were not greater than those obtained when insulin was injected at a rate of $0.035 \mathrm{U}$ per $\mathrm{Kg}$. per min- ute. This suggests that within the range tested, this process, in vivo, is not rate-limited, but rather that a fixed percentage of the insulin perfusing the liver per unit time is bound. This contention

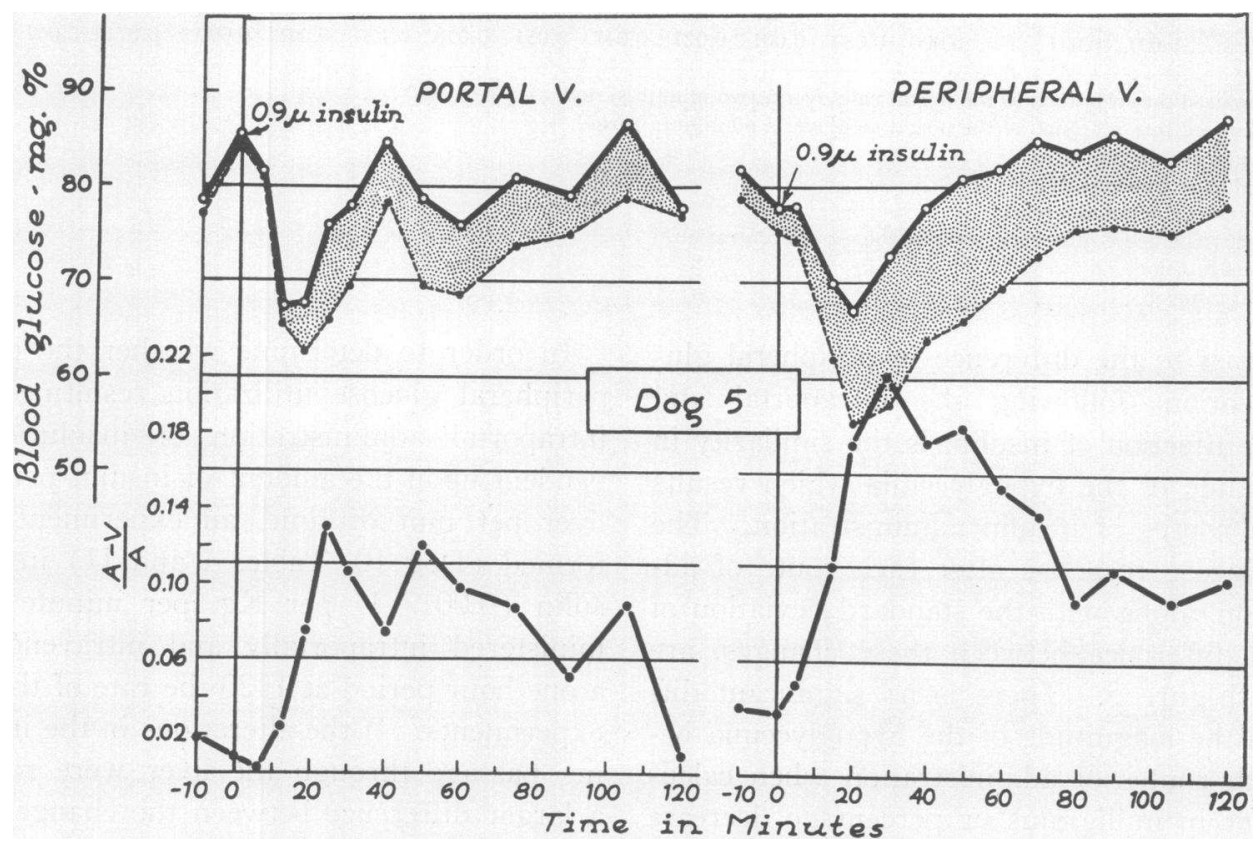

Fig. 2. Administration of Glucagon-Free Insulin (Dog 5) 


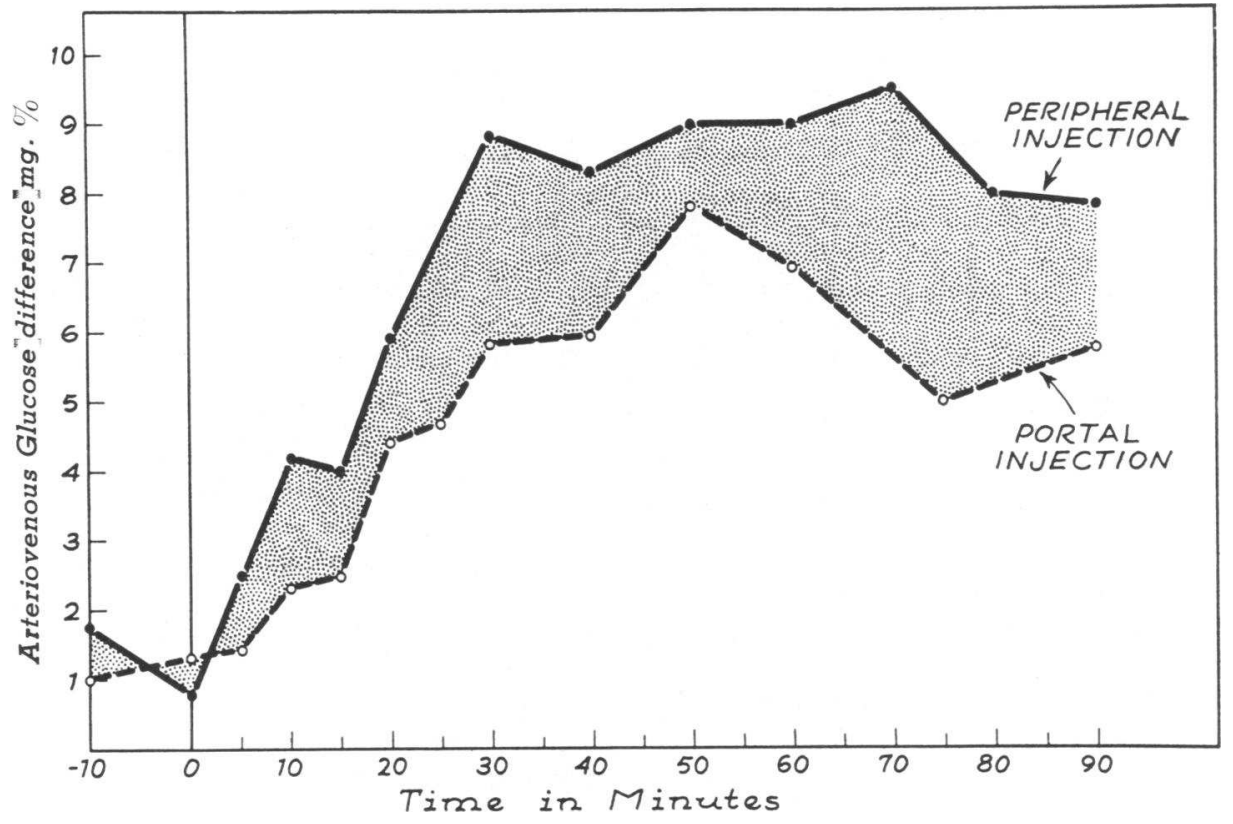

Fig. 3. Comparison of Changes in Mean Arteriovenous Glucose Difference after Peripheral and Portal Injection of Glucagon-Free Insulin

is supported by the finding of Lee and Williams that an elevenfold variation in the amount of insulin injected into rats had no effect on the per cent of the dose bound in the liver within $15 \mathrm{~min}$ utes (10).

\section{DISCUSSION}

The direct hepatic effect of insulin has long been a controversial issue (11). While the in vitro effects of insulin on the liver have been particularly difficult to demonstrate, in vivo effects of varying magnitude and duration have been shown (12-16). The evidence supporting an hepatic effect of insulin has recently been reviewed by de Duve (12) and Dunn, Friedmann, Maass, Reichard, and Weinhouse (13). If, as this evidence indicates, insulin alters hepatic glucose metabolism, then the reduction of blood glucose concentration which follows insulin administration is the consequence, not only of an in-

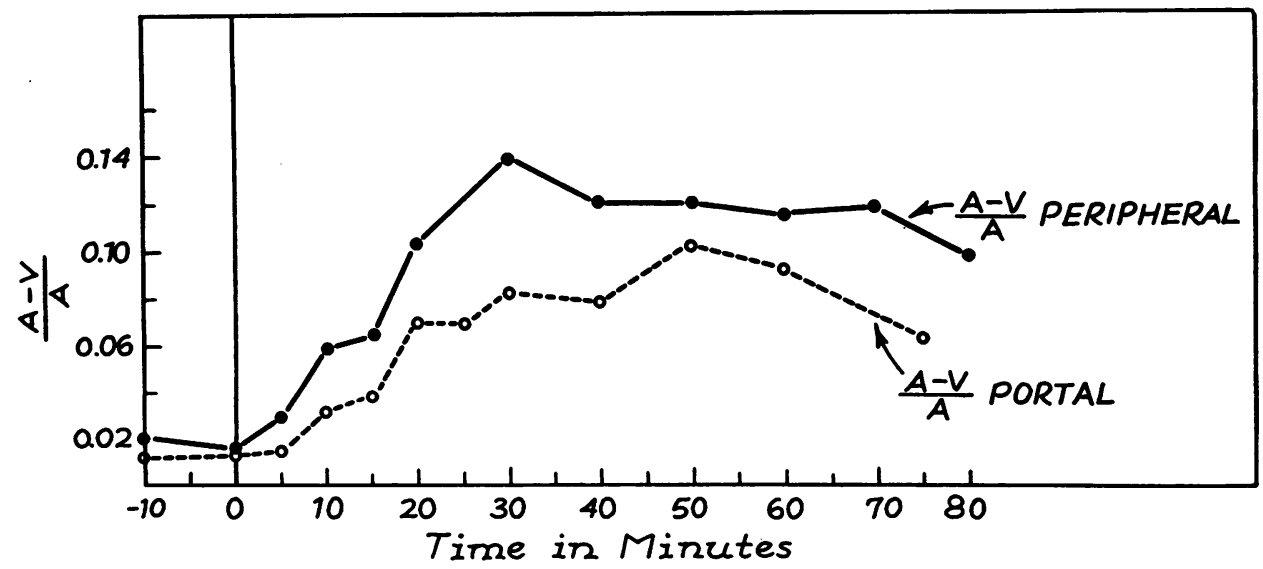

Fig. 4. Comparison of Mean Changes in (A-V)*/A after Peripheral and Portal Administration of Glucagon-Free Insulin

* Arteriovenous glucose difference/arterial glucose concentration. 
TABLE III

\begin{tabular}{|c|c|c|c|c|}
\hline \multirow{2}{*}{$\begin{array}{l}\text { Time } \\
\text { after } \\
\text { nsulin } \\
\text { ninutes) }\end{array}$} & \multicolumn{2}{|c|}{$\begin{array}{c}\text { Mean A-V*glucose } \\
(\mathrm{mg.})\end{array}$} & \multicolumn{2}{|c|}{$\underset{\mathrm{A}}{\mathrm{M}}$} \\
\hline & Periph. & Portal & Periph. & Portal \\
\hline $\begin{array}{r}-10 \\
0\end{array}$ & $\begin{array}{l}1.8 \\
0.8\end{array}$ & $\begin{array}{l}1.1 \\
1.3\end{array}$ & $\begin{array}{l}0.021 \\
0.016\end{array}$ & $\begin{array}{l}0.012 \\
0.014\end{array}$ \\
\hline $\begin{array}{r}5 \\
10 \\
15 \\
20 \\
25 \\
30 \\
40 \\
50 \\
60 \\
70 \\
75 \\
80\end{array}$ & $\begin{array}{l}2.5 \\
4.2 \\
3.9 \\
5.9 \\
\\
8.8 \\
8.4 \\
9.0 \\
8.6 \\
9.4 \\
8.0\end{array}$ & $\begin{array}{l}1.5 \\
2.2 \\
2.4 \\
4.3 \\
4.7 \\
5.7 \\
5.8 \\
7.7 \\
7.0 \\
4.9\end{array}$ & $\begin{array}{l}0.030 \\
0.059 \\
0.065 \\
0.103 \\
\\
0.139 \\
0.120 \\
0.120 \\
0.115 \\
0.118 \\
0.097\end{array}$ & $\begin{array}{l}0.015 \\
0.031 \\
0.039 \\
0.069 \\
0.070 \\
0.082 \\
0.079 \\
0.102 \\
0.092 \\
0.063\end{array}$ \\
\hline$\underset{p}{\text { Mean }}$ & ${ }^{6.9}<$ & $1^{4.6}$ & 0.097 & 0.064 \\
\hline
\end{tabular}

* Arteriovenous.

$\dagger$ Arteriovenous glucose difference/arterial glucose concentration.

creased peripheral glucose utilization, but also of a decreased hepatic output of glucose $(12,13)$. Increased peripheral glucose utilization in the intact animal is usually manifested by an increased A-V glucose difference $(5,9,17)$; whereas the decreased hepatic output of glucose, although contributing to the hypoglycemia, does not alter the A-V glucose difference.

A significantly smaller increase in $\mathrm{A}-\mathrm{V}$ glucose difference and therefore probably in peripheral

TABLE IV

Peripheral utilization indices after the peripheral and portal administration of insulin

\begin{tabular}{|c|c|c|c|c|}
\hline \multirow[b]{2}{*}{ Dog } & \multirow{2}{*}{$\begin{array}{c}\text { Duration } \\
\text { (minutes) }\end{array}$} & \multicolumn{2}{|c|}{$\begin{array}{c}\text { Sum of A-V* glucose } \\
\text { difference }\end{array}$} & \multirow{2}{*}{$\begin{array}{c}\text { Ratio } \\
\text { peripheral/ } \\
\text { portal }\end{array}$} \\
\hline & & Peripheral & Portal & \\
\hline $\begin{array}{r}1 \\
6 \\
5 \\
8 \\
3 \\
4 \\
2 \\
10\end{array}$ & $\begin{array}{r}120 \\
120 \\
120 \\
100 \\
80 \\
80 \\
80 \\
150\end{array}$ & $\begin{array}{r}153 \\
90 \\
129 \\
73 \\
55 \\
38 \\
17 \\
86\end{array}$ & $\begin{array}{r}101 \\
74 \\
70 \\
56 \\
37 \\
29 \\
8 \\
72\end{array}$ & $\begin{array}{l}1.52 \\
1.21 \\
1.84 \\
1.30 \\
1.48 \\
1.31 \\
2.12 \\
1.19\end{array}$ \\
\hline$\underset{p}{\text { Mean }}$ & \multicolumn{3}{|c|}{${ }^{80}<0.01^{56}$} & 1.49 \\
\hline
\end{tabular}

* Arteriovenous. glucose utilization was found after the endoportal, compared to the peripheral route of insulin administration. This could be the result of either an increased hepatic destruction of insulin by insulinase or an increased hepatic effect of the endoportally injected insulin. If the lesser augmentation of peripheral glucose utilization was accompanied by a decrease in the magnitude of the arterial hypoglycemia, the likelihood of a decreased delivery of insulin to the peripheral tissues resulting from hepatic inactivation of a portion of the intraportally injected insulin would be increased. No such difference was found. The magnitude of the arterial hypoglycemia was not

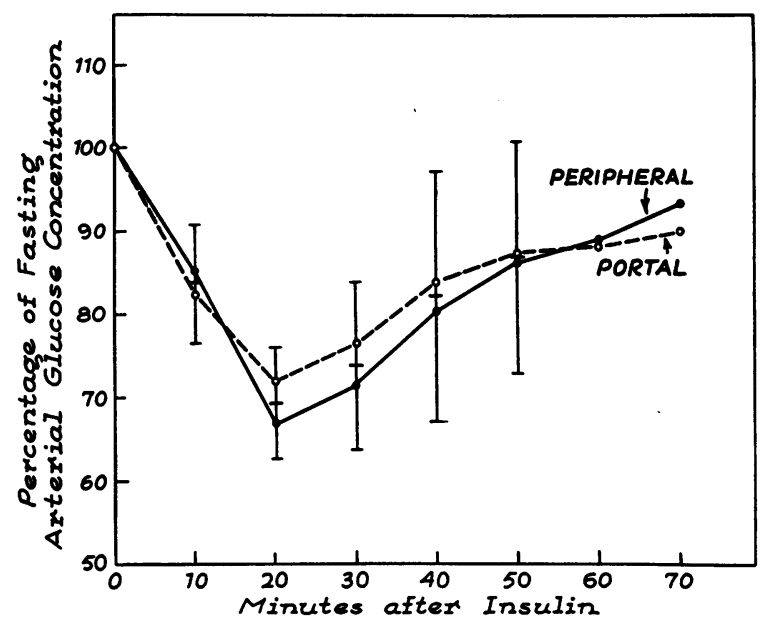

Fig. 5. Comparison of Mean Arterial Glucose ReSPONSE AFTer the INTRAPORTAL AND Peripheral AdMinistration OF GluCAgon-Free Insulin (0.07 U PER KG.)

significantly different after either route of administration. The combination of a similar degree of arterial hypoglycemia, coupled with a lesser increase in the $\mathrm{A}-\mathrm{V}$ glucose difference and therefore probably of peripheral glucose utilization, suggests an increased hepatic effect and a decreased peripheral effect of insulin administered via the portal vein. This interpretation of the data, although consonant with the effects of insulin on the peripheral tissues and on the liver $(12,13)$, is based on inferential changes in peripheral glucose utilization. Peripheral blood flow was not measured, and $\mathrm{A}-\mathrm{V}$ glucose differences alone were used as the index of peripheral glucose utilization. It is therefore possible that a greater 


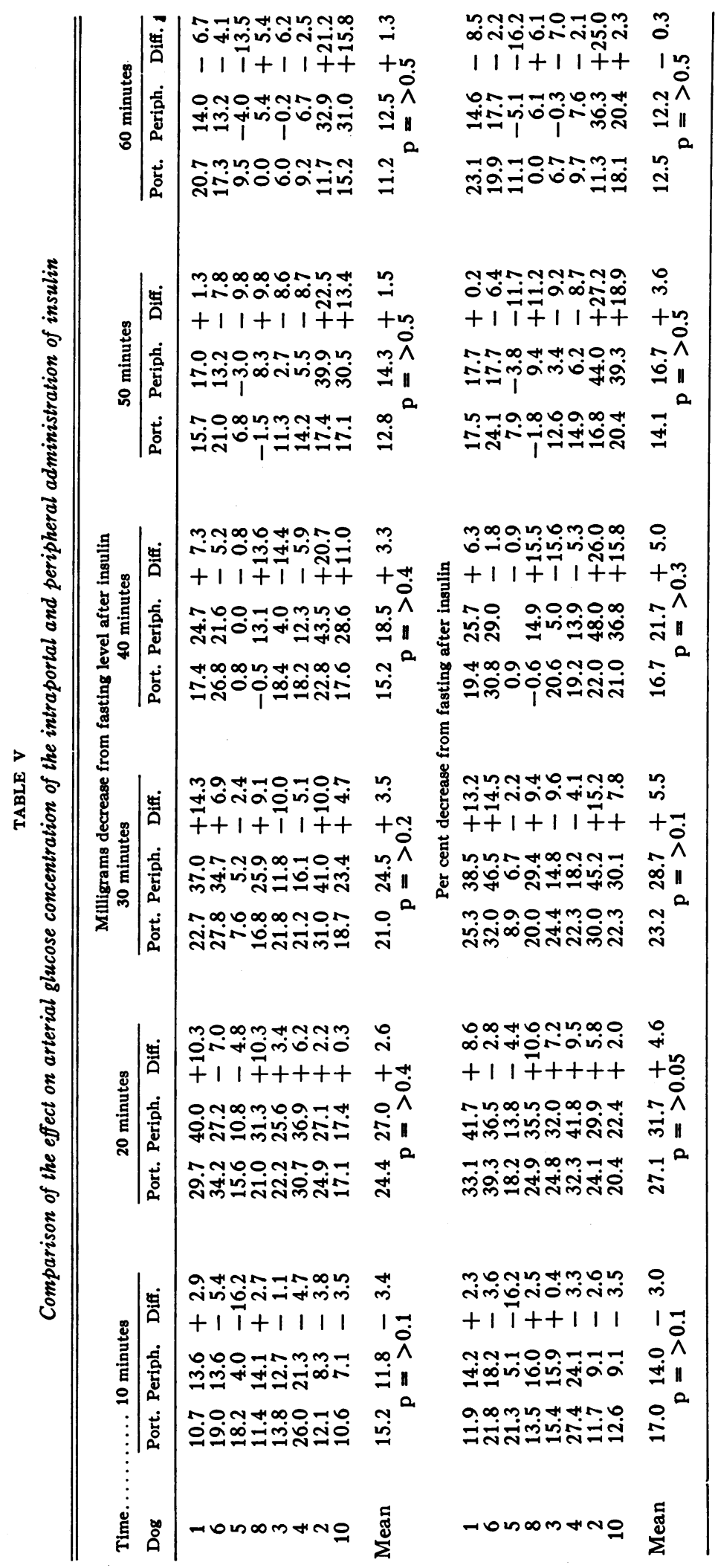


hypoglycemic effect from either route of administration was masked by the counterregulatory reactions which not only raised blood glucose concentrations, but also may have altered peripheral blood flow.

The difference between the metabolic effects of insulin injected endoportally and peripherally is probably causally linked with the increased amount of insulin, which reaches the liver after endoportal administration. Although the time of exposure of the liver to this larger amount of insulin is only a few seconds, i.e., the duration of a single circulation through the liver, other data indicate that exposure of an extremity to a large amount of insulin for a similar duration of time also augments the metabolic response of that limb (17). Bell and Burns showed that the intraarterial injection of insulin resulted in a significantly greater $\mathrm{A}-\mathrm{V}$ glucose difference in the injected leg compared to the contralateral extremity (17). In the intact animal, after the intravenous injection of insulin, the magnitude of the metabolic response of a tissue sensitive to insulin would be expected to depend, not only upon the affinity of the tissue for insulin, but also upon the per cent of the cardiac output perfusing the tissue per unit time, i.e., on the delivery of insulin to the tissue. When endogenous insulin is secreted into the portal vein, or exogenous insulin is injected endoportally, all of the insulin reaches the liver; by contrast, when insulin is injected into a peripheral vein, only a fraction of the amount given perfuses the liver.

Previous studies comparing the endoportal and peripheral routes of insulin administration were different from the present study. Arteriovenous glucose differences were not measured, and the studies were concerned primarily with the hyperglycemic effect of insulin $(18,19)$ presumably contaminated with glucagon. Weisberg, Freidman, and Levine (20) compared the hypoglycemic effects of the endoportal and peripheral routes of insulin administration, but they too did not measure $\mathrm{A}-\mathrm{V}$ glucose differences. In contrast to the results of the present study, Weisberg, Freidman, and Levine found a greater hypoglycemic effect after the peripheral route of injection. This was attributed to the hepatic inactivation or destruction (21-23) of insulin following portal injection. However, in all but two of their ex- periments insulin known to contain glucagon was used. The use of glucagon-containing insulin may have obscured any differences in the metabolic effects of insulin given endoportally and peripherally for at least two reasons: the hepatic glycogenolytic effect of the glucagon may have counterbalanced or masked the hepatic effect of insulin; glucagon may have augmented peripheral glucose utilization $(6,24)$. For these reasons the effects obtained with insulin known to contain glucagon are not comparable to those obtained with glucagon-free insulin.

The data suggest that the secretion of insulin into the portal vein has physiologic significance. By traversing the liver first, a greater hepatic effect and a smaller peripheral effect of insulin appear to be forthcoming, compared to that which follows the peripheral administration. This physiologic balance between the magnitude of the hepatic effect and the magnitude of the peripheral effect is apparently not duplicated by the peripheral administration of insulin. This finding may be of particular importance in experiments designed to demonstrate an hepatic effect of insulin and in the study of possible betacytotropic agents such as tolbutamide which may stimulate the endogenous secretion of insulin (25). The disparate views concerning the hepatic effect of insulin (11-13) and also the comparative effects of tolbutamide and insulin on peripheral utilization and glucose intermediaries (26-28) may have their explanations in the data herein presented.

\section{SUMMARY AND CONCLUSIONS}

Sixteen experiments were performed on eight dogs. In each dog during one experiment, glucagon-free insulin was administered via the portal vein to simulate the route traversed by endogenously secreted insulin and during the other, the same dose was administered into a peripheral vein in the foreleg. The endoportal administration of insulin resulted in the same degree of arterial hypoglycemia as the peripheral route of administration, and in a significantly reduced augmentation of peripheral glucose utilization, as evidenced by changes in the A-V glucose difference. These data suggest that a physiologic difference in the metabolic pattern, after insulin administration, occurs depending upon the route of administration. Endogenous insulin secreted into the portal 
vein may eventuate in a physiologic balance between the magnitude of the hepatic effect and the magnitude of the peripheral effect, which is apparently not duplicated by the peripheral administration of insulin.

\section{REFERENCES}

1. Stadie, W. C. Current concepts of the action of insulin. Physiol. Rev. 1954, 34, 52.

2. Stadie, W. C., Haugaard, N., and Vaughan, M. The quantitative relation between insulin and its biological activity. J. biol. Chem. 1953, 200, 745.

3. Haugaard, N., Haugaard, E. S., and Stadie, W. C. Combination of insulin with cells. J. biol. Chem. 1954, 211, 289.

4. Williams, R. H. Insulin distribution and degradation. Metabolism 1956, 5, 128.

5. Somogyi, M. Studies of arteriovenous glucose differences in blood sugar. I. Effect of alimentary hyperglycemia on the rate of extrahepatic glucose assimilation. J. biol. Chem. 1948, 174, 189.

6. Elrick, H., Hlad, C. J., Jr., and Witten, T. The enhancement of peripheral glucose utilization by glucagon. J. clin. Invest. 1955, 34, 1830.

7. Somogyi, M. Determination of blood sugar. J. biol. Chem. 1945, 160, 69.

8. Somogyi, M. Notes on sugar determination. J. biol. Chem. 1952, 195, 19.

9. Somogyi, M. Studies of arteriovenous differences in blood sugar. III. Effect of insulin administered intravenously in the postabsorptive state. J. biol. Chem. 1949, 179, 217.

10. Lee, N. D., and Williams, R. H. The intracellular localization of labeled thyroxine and labeled insulin in mammalian liver. Endocrinology 1954, 54, 5.

11. Levine, R., and Fritz, I. B. The relation of insulin to liver metabolism. Diabetes 1956, 5, 209.

12. de Duve, C. The hepatic action of insulin in Ciba Foundation Colloquia on Endocrinology. Boston, Little, Brown and Co., 1956, vol. 9, p. 203.

13. Dunn, D. F., Freidmann, B., Maass, A. R., Reichard, G. A., and Weinhouse, S. Effects of insulin on blood glucose entry and removal rates in normal dogs. J. biol. Chem. 1957, 225, 225.

14. Bearn, A. G., Billing, B. H., and Sherlock, S. Response of the liver to insulin; Hepatic vein catheterization studies in man in Ciba Foundation Colloquia on Endocrinology. Boston, Little, Brown and Co., 1953, vol. 6, p. 250.

15. Wall, J. S., Steele, R., de Bodo, R. C., and Altszuler, $\mathrm{N}$. Effect of insulin on utilization and production of circulating glucose. Amer. J. Physiol. 1957, $189,43$.

16. Henderson, M. J., Wrenshall, G. A., and Odense, P. Effects of insulin on rates of glucose transfer in the depancreatized dog. Canad. J. Biochem. 1955, 33, 926.

17. Bell, D. M., and Burns, T. Effect on femoral A-V glucose difference of insulin injected into antecubital vein and into femoral artery. J. clin. Invest. 1952, 31, 717.

18. Collens, W. S., and Murlin, J. R. Hyperglycemia following the portal injection of insulin. Proc. Soc. exp. Biol. (N. Y.) 1928-29, 26, 485.

19. Neuwirth, I., Co Tui, F., and Wallace, G. B. The so-called hyperglycemia action of insulin. Proc. Soc. exp. Biol. (N. Y.) 1929-30, 27, 194.

20. Weisberg, H. F., Freidman, A., and Levine, R. Inactivation or removal of insulin by the liver. Amer. J. Physiol. 1949, 158, 332.

21. Mirsky, I. A. The insulinase and insulinase-inhibitor activity of the liver in Ciba Foundation Colloquia on Endocrinolgy. Boston, Little, Brown and Co., 1953, vol. 6, p. 263.

22. Mirsky, I. A., and Perisutti, G. The inactivation of insulin by liver slices of the rat. Endocrinology 1953, 52, 698.

23. Tomizawa, H. H., Nutley, M. L., Narahara, H. T., and Williams, R. H. Inactivation of insulin by rat liver extracts. J. Amer. chem. Soc. 1954, 76, 3357.

24. Elrick, H., Hlad, C. J., Jr., Arai, Y., and Smith, A. The interaction of glucagon and insulin on blood glucose. J. clin. Invest. 1956, 35, 757.

25. Madison, L. L., and Unger, R. H. Comparison of the effects of insulin and Orinase (tolbutamide) on peripheral glucose utilization in the dog. Metabolism. In press.

26. Renold, A. E., Winegrad, A. I., Froesch, E. R., and Thorn, G. W. Studies on the site of action of arysulfonylureas in man. Metabolism 1956, 5, 757.

27. Hennes, A. R., Wajchenberg, B. L., Fajans, S. S., and Conn, J. W. Comparative effects of insulin and Orinase on blood levels of pyruvate and alphaketoglutarate in normal subjects. Metabolism 1957, 6, 63.

28. Miller, M., Craig, J. W., Mackenzie, M. S., Drucker, W. R., Cammarn, M., and Woodward, H., Jr. Studies of the effect of intravenous tolbutamide on pyruvic and lactic acid concentrations in peripheral venous blood in normal and diabetic subjects and on splanchnic metabolism of fructose and glucose. I. Comparison of effects of insulin and tolbutamide on concentrations of glucose, pyruvic acid, and lactic acid in peripheral venous blood. Ann. N. Y. Acad. Sci. 1957, 71, 51. 